\title{
Global climate change - the technology challenge
}

\author{
F. T. Princiotta \\ Air Pollution Prevention and Control Division, National Risk \\ Management Research Laboratory, Office of Research and Development, \\ US Environmental Protection Agency, USA
}

\begin{abstract}
Anthropogenic emissions of greenhouse gases, such as carbon dioxide, have led to increasing atmospheric concentrations which are at least partly responsible for the roughly $0.7^{\circ} \mathrm{C}$ global warming earth has experienced since the industrial revolution. With industrial activity and population expected to increase for the rest of the century, large increases in greenhouse gas emissions are projected, with additional and potentially substantial subsequent global warming predicted. The paper provides a brief overview of the factors driving $\mathrm{CO}_{2}$ emissions for the world and for selected countries, an examination of key technologies that would be required for an aggressive mitigation program, and a concise sector-by-sector summary of mitigation options, along with $R \& D$ priorities.
\end{abstract}

\section{Introduction}

The Intergovernmental Panel on Climate Change [1] concluded in 2001 that anthropogenic emissions of greenhouse gases, such as carbon dioxide $\left(\mathrm{CO}_{2}\right)$, have led to increasing atmospheric concentrations which are to be at least partly responsible for the roughly $0.6^{\circ} \mathrm{C}$ global warming earth has experienced since the industrial revolution. Since 2001, warming has now increased to an estimated $0.7^{\circ} \mathrm{C}(\mathrm{NCAR}[2])$

In Figure 1, IPCC [1] has summarized historical and projected trends for atmospheric concentrations of $\mathrm{CO}_{2}$. In order to make these projections, the Panel evaluated a range of scenarios, including alternative business-as-usual cases and various mitigation scenarios. As Figure 1 shows, the projected concentrations can be as high as $1000 \mathrm{ppm}$ compared to a pre-industrial level of $280 \mathrm{ppm}$ and a 
current level of $382 \mathrm{ppm}$. This increase in $\mathrm{CO}_{2}$ concentration and the contributions of other greenhouse gases are the major driving force for global warming.

The author will now discuss the factors that lead to increasing emissions of $\mathrm{CO}_{2}$ and the anticipated contribution of key countries. Then, $\mathrm{CO}_{2}$ emissions will be projected into the future for key sectors. Finally, the author will summarize the state of the art of key technologies and R\&D priorities for each of four key sectors that can contribute to mitigating such emissions. (Not that in this paper, all $\mathrm{CO}_{2}$ concentrations will be in ppmv and all warming will be realized or transient warming, as opposed to equilibrium warming.)

Although, the scope of this paper is limited to a consideration of technologies that could play a major role in reducing $\mathrm{CO}_{2}$ emissions, it is important to note that availability of key technologies will be necessary but not sufficient to constrain emissions. Since many of these technologies have higher costs and/or greater operational uncertainties than currently available carbon intensive technologies, robust policies will need to be in place to encourage their utilization.

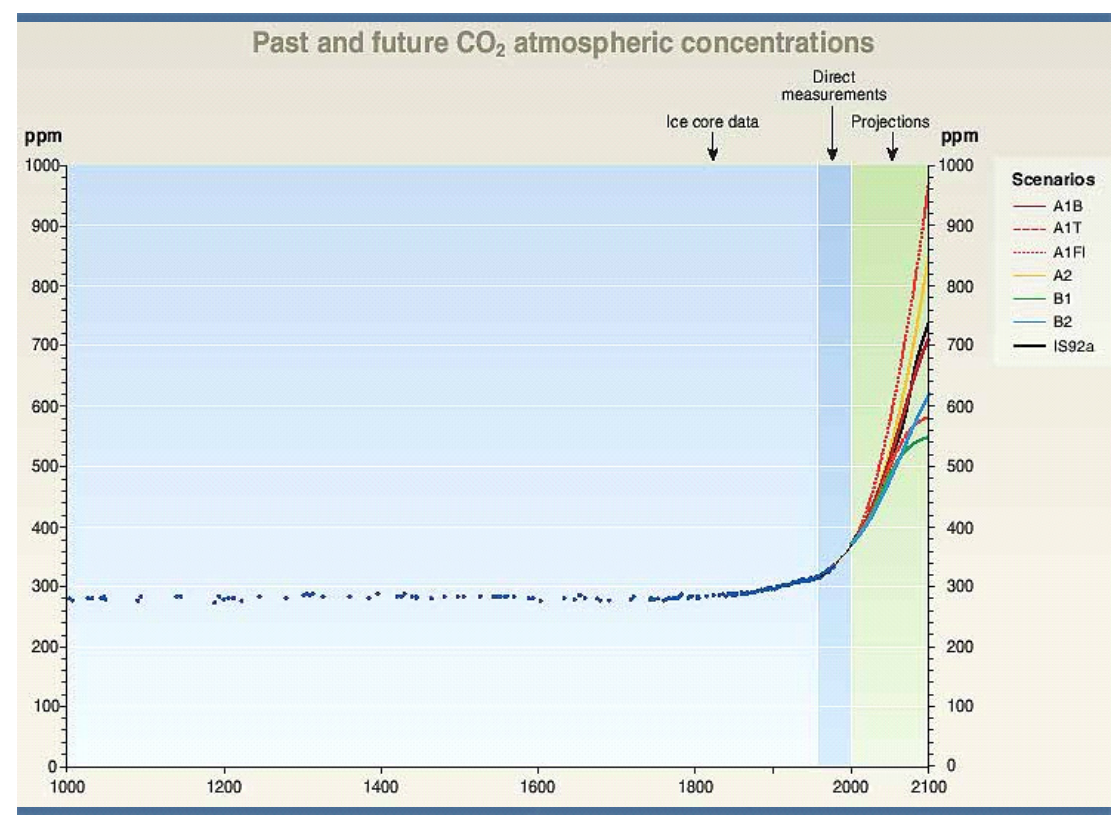

Figure 1: Past and projected atmospheric concentrations of $\mathrm{CO}_{2}$.

\section{Factors that drive emissions of $\mathrm{CO}_{2}$}

The World Resources Institute [3] has examined the factors that have driven $\mathrm{CO}_{2}$ emissions for key countries in the 1992 to 2002 time period. The factors 
considered are: Gross Domestic Product (GDP) ((Purchasing Power Parity (Intl \$)), growth per capita, population growth, carbon intensity growth per unit of energy (more coal in the mix increases this factor), and the growth of energy usage per unit of GDP. The sum of these factors approximates the annual $\mathrm{CO}_{2}$ emission growth rate. The author has used the Institute's data to generate Figure 2, which shows how these factors have influenced the annual growth rate of $\mathrm{CO}_{2}$ for selected countries during this ten-year period. As can be seen for the world, despite decreases in the energy use per unit of GDP, the $\mathrm{CO}_{2}$ growth rate was about $1.5 \%$ per year. The rate for the U.S. also has been about $1.5 \%$, but the growth rate for China and India has been about 4\% per year, driven by economic growth, and for India, population growth as well. Note that in the absence of significant decreases in energy use per unit of economic output, $\mathrm{CO}_{2}$ emission growth rates would have been substantially greater.

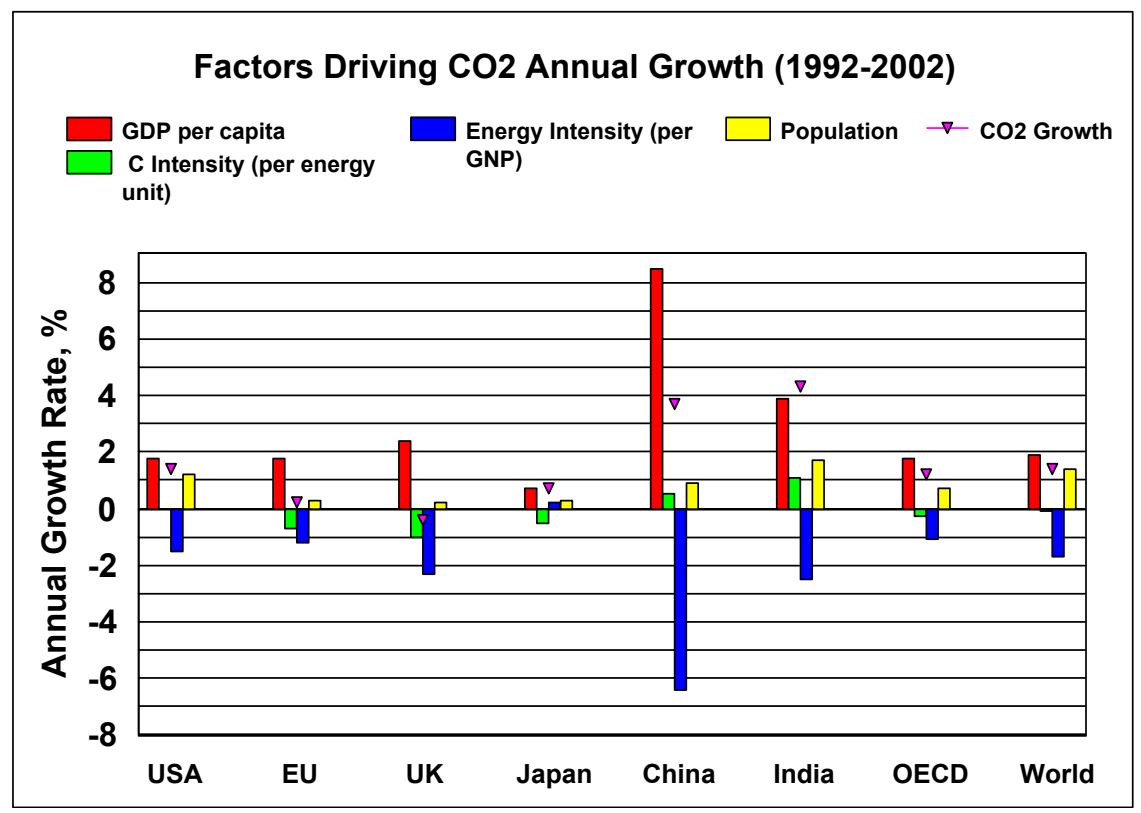

Figure 2: Factors driving $\mathrm{CO}_{2}$ emissions for selected countries.

If these trends continue, first China and then India will surpass the U.S. as the largest $\mathrm{CO}_{2}$ emitter in the coming decades. The main driver for this accelerating trend for these populous Asian countries is their expected high rate of economic growth as they strive for a standard of living approaching those of the developed countries. 


\section{The mitigation challenge; which sectors and gases are most important?}

In order to identify the most promising mitigation technologies, it is necessary to understand the current and projected sources of $\mathrm{CO}_{2}$ and the other greenhouse gases. The author has derived the information in Figure 3 from IEA [4]. This graphic projects world $\mathrm{CO}_{2}$ emissions by sector; it suggests that power generation and transportation sources will be the fastest growing and will be the key to any successful mitigation program. This IEA baseline scenario, assumes a continuation of $\mathrm{CO}_{2}$ emission growth consistent with Figure 2: for 2000 to 2030, $1.5 \%$; and for 2030 to 2050 , a $2.2 \% \mathrm{CO}_{2}$ growth rates. As mentioned earlier, China and India, with a cumulative population of over 2.4 billion, are projected to continue their rapid economic expansion with commensurate pressure on the power generation and transportation sectors. It should also be noted that the energy transformation category in Figure 3 includes petroleum refining, natural gas and coal conversion to liquids and biomass to alcohols, much of which will feed the transportation sector.

For the U.S., The World Resources Institute [5] has generated a very informative graphic. Figure 4 illustrates the relationship between sectors, end use/activities, greenhouse gases, and the resulting driving force for warming for the year 2000 .

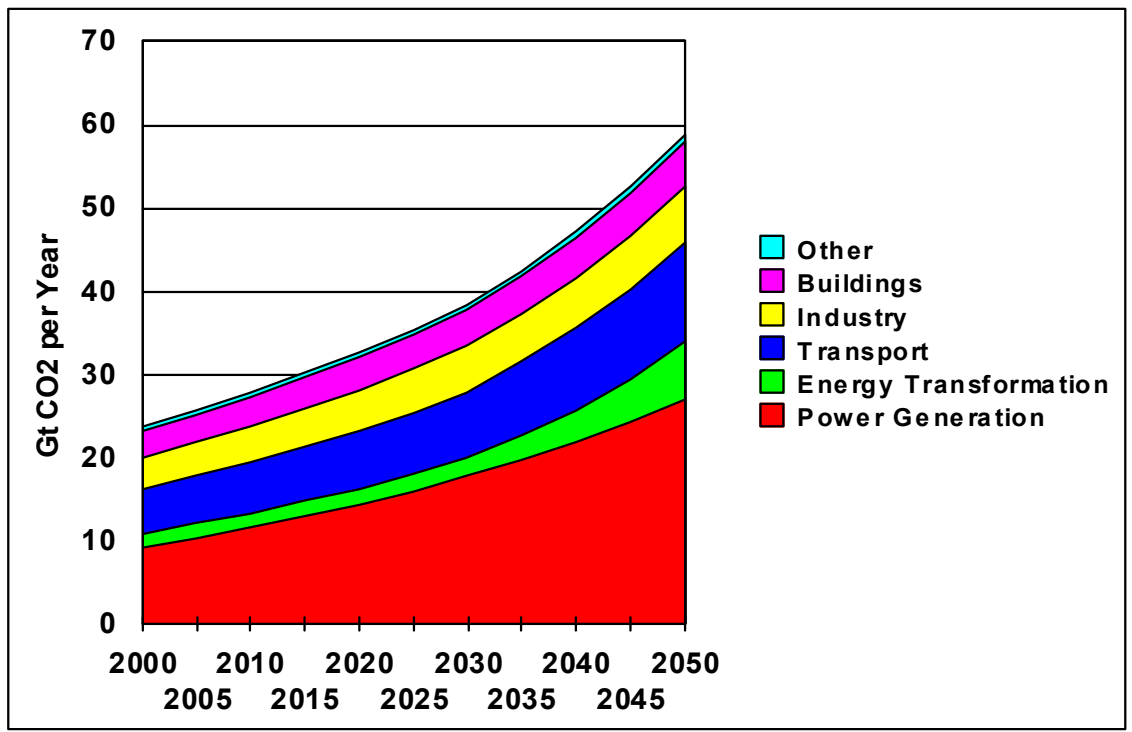

Figure 3: Projected world $\mathrm{CO}_{2}$ emission growth for key economic sectors. 


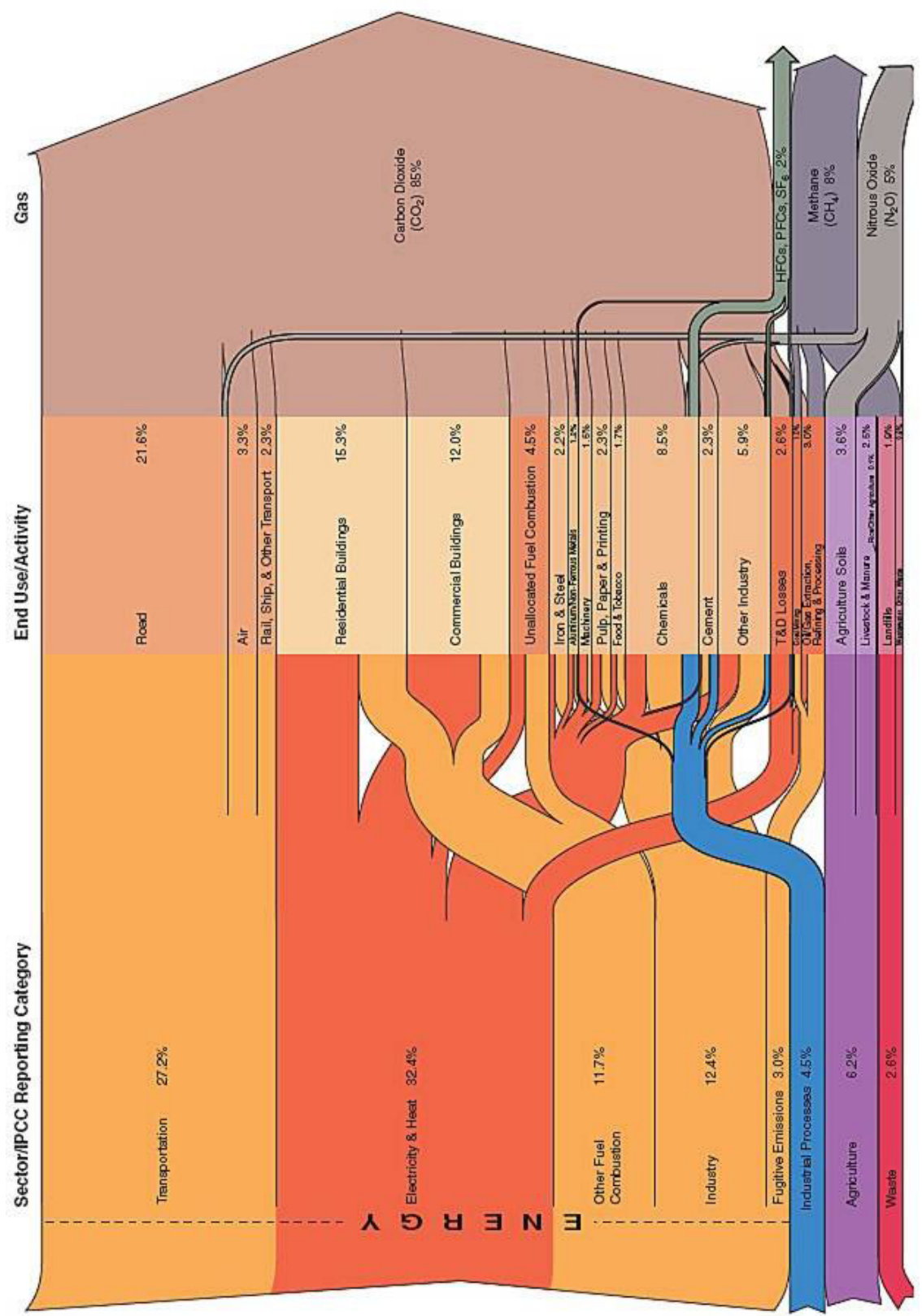

Figure 4: GHG emission flows by sector, end use, and gas in 2000.

This graphic also illustrates the relationship of power generation (electricity and waste heat in the figure), and its end use in the building and industrial sectors. 
At this point it should be acknowledged that certain gases other than $\mathrm{CO}_{2}$ contribute significantly to warming. Figure 4 illustrates this for the U.S. Although $\mathrm{CO}_{2}$ is the dominant driver, methane and nitrous oxide are significant. For the international view of the relative significance of the key greenhouse gases, the author has generated Figure 5 using the MAGICC model (Wigley and Raper [6]). This figure illustrates the relative thermal forcing of the key greenhouse gases for 2020, 2050, and 2100 using emission projections consistent with the author's modified IEA base case for $\mathrm{CO}_{2}$ and IPCC [1] Scenario WRE750 for the other greenhouse gases. Note that fine particles show a cooling effect in 2020, which transforms to a warming effect in later years. This is explained since emissions of sulfur dioxide are projected to increase until 2020 , whereas the emissions will be reduced later in the century as countries install $\mathrm{SO}_{2}$ controls. With such emission control, concentrations of sulfate particles, which reflect incoming solar radiation, will consequently be lower, and their cooling effect reduced, yielding warming relative to 1990 .

For this paper, the focus will be on $\mathrm{CO}_{2}$, since it is the critical greenhouse gas.

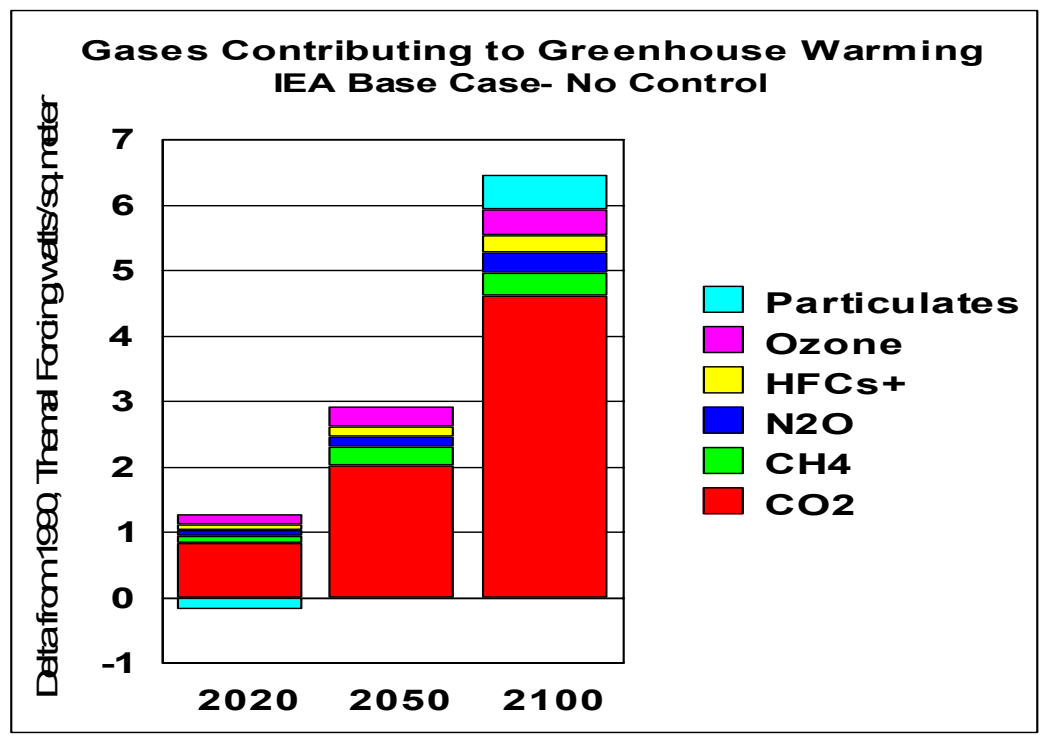

Figure 5: Relative driving force of major greenhouse gases.

\section{The mitigation challenge; what role can energy technology play and what are the options:}

Although this paper will focus on energy technologies, it should be noted that complimentary approaches could be significant as well. They include life style 
changes, such as lowering thermostats in the winter and minimizing driving mileage, and more energy efficient urban planning, which could facilitate mass transit rather than car and truck transport. Also, as suggested by Figure 5, methane, ozone and nitrous oxide mitigation approaches could be significant for the roughly $20 \%$ of the thermal forcing associated with them. Finally, there have been various geoengineering approaches suggested which could potentially help buy time until new energy technologies are developed and deployed. For example, Wigley [7] suggested simulating volcanoes, which are known to cool the planet after high altitude eruptions, by purposely emitting large quantities of sulfate particles into the stratosphere. The objective would be to reflect incoming solar radiation. Of course such approaches are very early in their design and would have to be carefully evaluated for their economic and environmental impacts.

In order to understand the potential of various energy technologies to mitigate $\mathrm{CO}_{2}$ emissions, IEA [4] recently evaluated what it called Accelerated Technology (ACT) scenarios. Of these, the ACT Map scenario is the most optimistic, assuming an aggressive and successful R, D \& D program to improve commercial or near commercial technologies and a comprehensive demonstration and deployment program for key technologies. It also assumes policies in place that would encourage the use of these technologies in an accelerated time frame. These include $\mathrm{CO}_{2}$ reduction incentives to encourage low-carbon technologies of cost up to $\$ 25 / \mathrm{T} \mathrm{CO}_{2}$ in all countries from 2030 to 2050. The incentives could take the form of regulation, pricing, tax breaks, voluntary programs, subsidies, or trading schemes.

The author has generated Figure 6, which projects $\mathrm{CO}_{2}$ emissions by sector, for the ACT Map scenario, based on their assumption that major technology implementation starts in 2030. Figure 7 depicts the $\mathrm{CO}_{2}$ savings projected by sector using the ACT Map scenario. Most of the savings relate to the power generation sector, which includes both production and end use savings. This IEA scenario is projected to result in the mitigation of $32.5 \mathrm{Gt}$ of $\mathrm{CO}_{2}$ in 2050. As will be discussed subsequently, this level of mitigation, would be impossible without the use of improved and in some cases breakthrough energy technologies. Such technologies are necessary for both energy production, i.e., power generation, and to enhance end use efficiency, i.e., lower emission vehicles.

It is important to note that for the IEA Map scenario extended to 2100, the author's MAGICC (Wigley and Raper [6]) calculations indicate best-guess $\mathrm{CO}_{2}$ concentrations in 2100 of $500 \mathrm{ppm}$ and a corresponding warming of $2.0^{\circ} \mathrm{C}$ relative to 1990 . This is despite the IEA assumption of an aggressive R,D\&D and deployment program and the author optimistically assuming further major $(2 \%$ per year) emission reductions for 50 years beyond the IEA time frame of 2050 . This suggests that even a major mitigation program, globally implemented, based on successful development and deployment of several new technologies, will still allow substantial global warming in 2100 . 


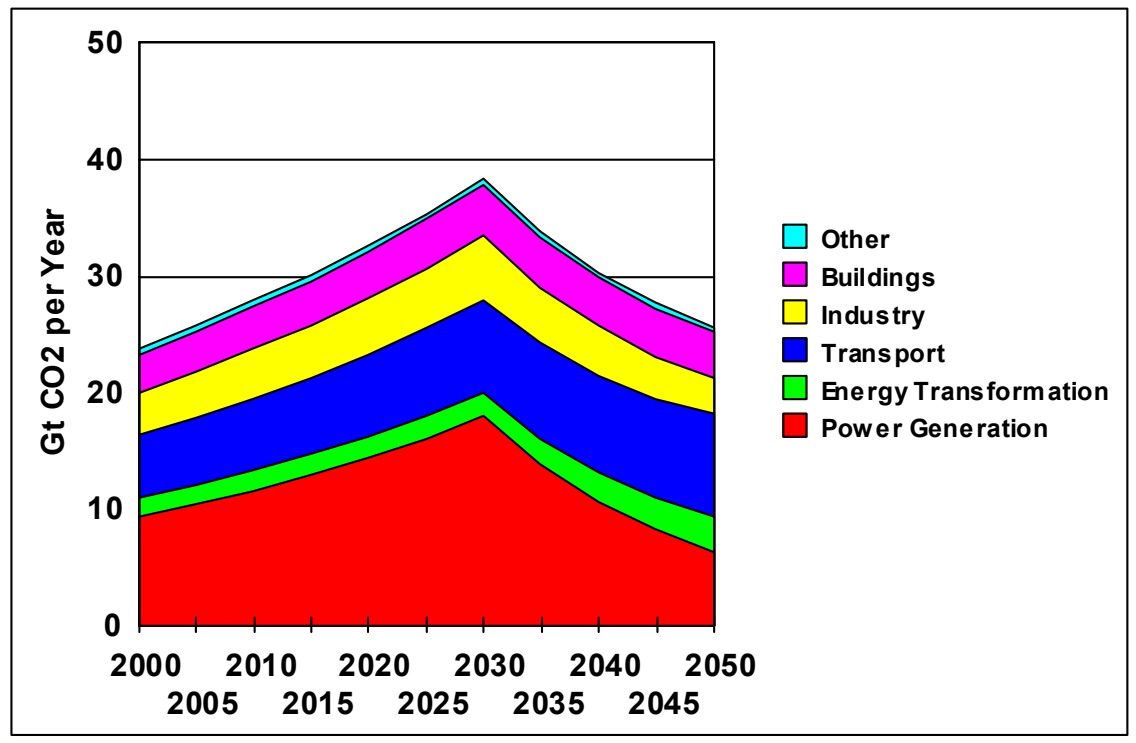

Figure 6: Sector $\mathrm{CO}_{2}$ emissions for the IEA ACT scenario.

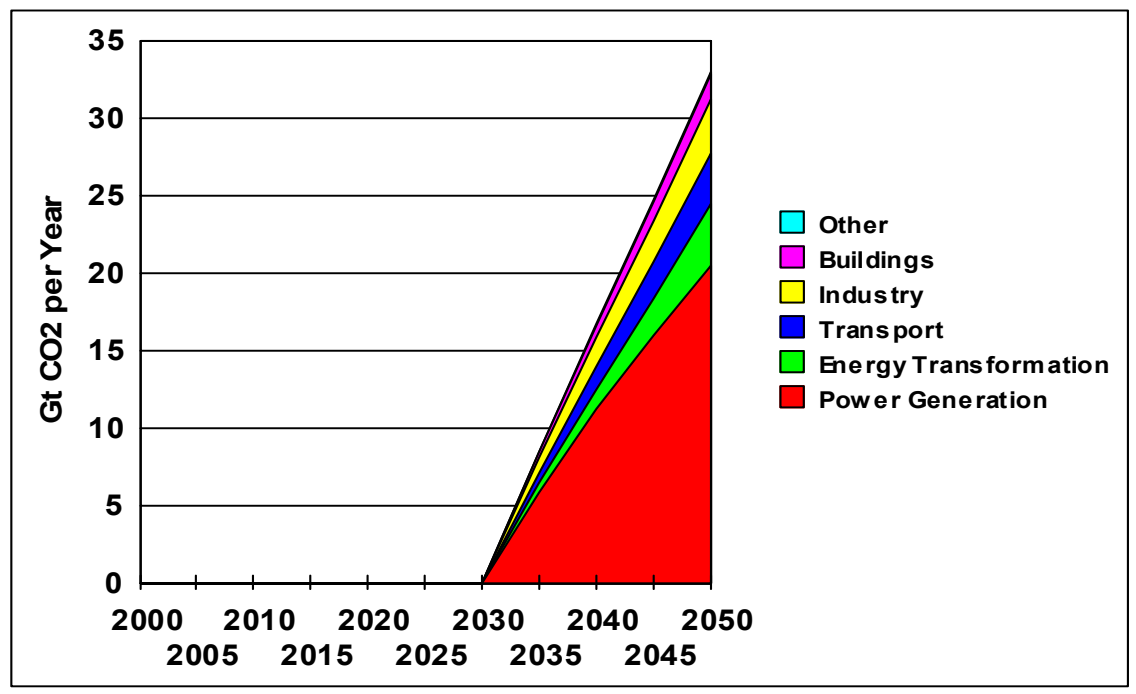

Figure 7: $\mathrm{CO}_{2}$ emission reductions per sector for the ACT scenario.

The author has generated Tables 1-4 for the key four sectors to summarize the potential and status of key technologies based on the following recent energy technology assessments: IEA [4], Hawksworth [8], Pacala and Socolow [9], Morgan et al. [10]. Two additional references contained useful information relative to hydrogen/fuel cells, USEPA [11], and nuclear technologies, USEPA [12]. 
Let us now focus on these four critical sectors and examine the technology options available, their current state of the art, and the required R, D\&D to allow the technology options to meet their potential to reduce $\mathrm{CO}_{2}$ emissions.

\section{Power generation sector}

Of all the sectors, the power generation sector, which is projected to grow at an annual rate of $2 \%$, has the greatest potential to reduce $\mathrm{CO}_{2}$ emissions in the coming decades. However, it should be noted that there are major capacity expansions underway for coal-fired power generation in China, India, and other countries. Since such plants have no $\mathrm{CO}_{2}$ mitigation technology planned and can have lifetimes up to 50 years, the sooner technology is ready for implementation and mandated, the sooner new plants can incorporate such technology and control emissions. Carbon dioxide retrofit technology is theoretically possible, but such technology will not be commercially available for some time and will likely be substantially more expensive per unit of power generated than would be the case for new plants.

Major reductions can result from lower emissions on the generation side and as a result of lower usage via enhanced end use efficiency. Table 1 presents a summary of major generation options that offer significant opportunities for $\mathrm{CO}_{2}$ mitigation. They are presented in the order of highest potential for $\mathrm{CO}_{2}$ mitigation consistent with the IEA ACT Map scenario. Included in this and the subsequent tables are the IEA projected $\mathrm{CO}_{2}$ savings for each technology in $\mathrm{Gt}$ of $\mathrm{CO}_{2}$ in 2050. To put these numbers in perspective, full implementation of the IEA Map scenario would mitigate $32.5 \mathrm{Gt}$ of $\mathrm{CO}_{2}$.

Key generation technologies include nuclear power, natural gas/combined cycle, and three coal combustion technologies (IGCC, pulverized coal/oxygen combustion, and conventional pulverized coal), all with integrated $\mathrm{CO}_{2}$ capture and underground storage. With the exception of wind power, renewable technologies (green font in Table 1) are not projected to have major mitigation impacts in the 2050 time frame. In the case of solar generation, the technology is projected to be prohibitively expensive unless there is a major research breakthrough. For biomass, major utilization is projected to be limited by its dispersed nature, its low energy density, and competition for the limited resource in the transportation sector.

The author rates $\mathrm{R}, \mathrm{D} \& \mathrm{D}$ needs in the power generation sector particularly critical, especially in the area of $\mathrm{CO}_{2}$ capture and storage (CCS) and for the next generation of nuclear power plants. The CCS area is in the early developmental stage, with extraordinary potential, but with a host of questions that can only be resolved through a major program with a particular focus on demonstrations for the key geological formations, most applicable to the greatest potential capacity. For advanced nuclear power, the technology is quite promising and could start making a major impact by 2030 . However, technology needs a number of successful demonstrations to allow for resolution of remaining technical problems and to instill confidence in the utility industry that the technology is affordable and reliable, and in the public, that it is safe. 
Table 1: Key technologies for $\mathrm{CO}_{2}$ avoidance from power generation (projected impact in $\mathrm{Gt} / \mathrm{Yr}$ of $\mathrm{CO}_{2}$ ).

\begin{tabular}{|c|c|c|c|c|c|}
\hline Technology & $\frac{\text { Current State of the }}{\text { Art }}$ & $\frac{2050}{\text { Impact }}$ & Issues & R,D\&D Needs & $\begin{array}{c}\text { Other Potential } \\
\text { Environmental Impacts }\end{array}$ \\
\hline $\begin{array}{l}\text { Nuclear Power- } \\
\text { next generation }\end{array}$ & $\begin{array}{l}\text { Developmental, } \\
\text { Generation III+ and IV: } \\
\text { e.g. Pebble Bed } \\
\text { Modular Reactor and } \\
\text { Supercritical Water } \\
\text { Cooled Reactor }\end{array}$ & 1.9 & $\begin{array}{l}\text { Deployment targeted by } \\
2030 \text { with a focus on lower } \\
\text { cost, minimal } \\
\text { waste,enhanced safety and } \\
\text { resistance to proliferation }\end{array}$ & $\begin{array}{l}\text { High, Demonstrations of key } \\
\text { technologies with } \\
\text { complimentary research on } \\
\text { important issues }\end{array}$ & $\begin{array}{l}\text { Reduction in emissions of } \\
\text { SOx, NOx, Fine PM; small } \\
\text { but potent and long-lived } \\
\text { waste, could contaminate } \\
\text { small area }\end{array}$ \\
\hline $\begin{array}{l}\text { Nuclear Power- } \\
\text { current } \\
\text { generation }\end{array}$ & $\begin{array}{l}\text { Commercial, } \\
\text { Pressurized Water } \\
\text { Reactors and Boiling } \\
\text { Water Reactors } \\
\text { (Generation III) }\end{array}$ & 1.8 & \begin{tabular}{|l|} 
Plant siting, high capital \\
costs, levelized cost 10 to \\
$40 \%$ higher than coal or gas \\
plants, potential U shortages, \\
safety, waste disposal and \\
proliferation
\end{tabular} & $\begin{array}{l}\text { Medium, Waste disposal } \\
\text { research }\end{array}$ & $\begin{array}{l}\text { Reduction in emissions of } \\
\text { SOx, NOx, Fine PM; small } \\
\text { but potent and long-lived } \\
\text { waste, could contaminate } \\
\text { small area }\end{array}$ \\
\hline $\begin{array}{l}\text { Natural Gas } \\
\text { Combined } \\
\text { Cycle }\end{array}$ & $\begin{array}{l}\text { Commercial, } 60 \% \\
\text { efficiency }\end{array}$ & 1.6 & $\begin{array}{l}\text { Limited by natural gas } \\
\text { availability, which is major } \\
\text { constraint; high effiency \& } \\
\text { low capital costs, extraction } \\
\text { R\&D coud enhance } \\
\text { availability of } \mathrm{CH} 4 \\
\end{array}$ & $\begin{array}{l}\text { Medium, higher efficiencies } \\
\text { with new materials desirable }\end{array}$ & $\begin{array}{l}\text { Reduction in emissions of } \\
\text { SOx, NOx, Fine PM; fewer } \\
\text { mining impacts and residues }\end{array}$ \\
\hline $\begin{array}{l}\text { Wind Power } \\
\text { (renewable) }\end{array}$ & Commercial & 1.3 & $\begin{array}{l}\text { Costs very dependent on } \\
\text { strength of wind source, } \\
\text { large turbines visually } \\
\text { obtrusive, intermittent power } \\
\text { source }\end{array}$ & $\begin{array}{l}\text { Medium, higher efficiencies, } \\
\text { on-shore demonstrations }\end{array}$ & $\begin{array}{l}\text { Reduction in emissions of } \\
\text { SOx, NOx, Fine PM; fewer } \\
\text { mining impacts and residues }\end{array}$ \\
\hline $\begin{array}{l}\text { Coal IGCC with } \\
\text { CO2 Capture } \\
\text { and } \\
\text { Underground } \\
\text { Storage }\end{array}$ & $\begin{array}{l}\text { IGCC: early } \\
\text { commercialization, } \\
\text { Underground storage } \\
\text { (US) : early } \\
\text { development. }\end{array}$ & 1.3 & $\begin{array}{l}\text { IGCC:High capital costs, } \\
\text { questionable for low rank } \\
\text { coals,complexity and } \\
\text { potential reliability concerns; } \\
\text { US: Cost, safety, efficacy }\end{array}$ & $\begin{array}{l}\text { High, IGCC: Demos on a } \\
\text { variety of coals, hot gas } \\
\text { cleanup research; US: major } \\
\text { program with long term } \\
\text { demos evaluating large } \\
\text { number of geological } \\
\text { formations to evaluate } \\
\text { efficacy, cost and safety }\end{array}$ & $\begin{array}{l}\text { Lower power plant efficiency } \\
\text { yields greater emissions of } \\
\text { SOx, NOx, Fine PM } \\
\end{array}$ \\
\hline $\begin{array}{l}\text { Pulverized } \\
\text { Coal/Oxy } \\
\text { combustion } \\
\text { with } \mathrm{CO} 2 \\
\text { Capture and } \\
\text { Storage }\end{array}$ & Developmental & 1.3 & $\begin{array}{l}\text { Oxygen combustion allows } \\
\text { lower cost CO2 scrubbing, } \\
\text { but oxygen production cost is } \\
\text { high; US: Cost, safety and } \\
\text { permanency }\end{array}$ & $\begin{array}{l}\text { High, large pilot followed by } \\
\text { full scale demos needed, low } \\
\text { cost } \mathrm{O}_{2} \text { production needed, } \\
\text { US requires major program } \\
\text { (see write-up above) }\end{array}$ & $\begin{array}{l}\text { Lower power plant efficiency } \\
\text { yields greater emissions of } \\
\text { SOx, NOx, Fine PM }\end{array}$ \\
\hline \begin{tabular}{|l|} 
Pulverized Coal \\
with $\mathrm{CO} 2$ \\
Capture and \\
Storage
\end{tabular} & $\begin{array}{l}\text { Underground storage } \\
\text { developmental; CO2 } \\
\text { scrubbing with MEA } \\
\text { near commercial but } \\
\text { too expensive }\end{array}$ & 1.3 & $\begin{array}{l}\text { US: Cost, safety and efficacy } \\
\text { issues, } \mathrm{CO}_{2} \text { scrubbing } \\
\text { energy intensive: yielding } \\
\text { unacceptable costs }\end{array}$ & $\begin{array}{l}\text { High, US requires major } \\
\text { program (see write-up } \\
\text { above); affordable } \mathrm{CO}_{2} \\
\text { removal technologies need } \\
\text { to be developed and } \\
\text { demonstrated }\end{array}$ & $\begin{array}{l}\text { Lower power plant efficieny } \\
\text { yields greater emissions of } \\
\text { SOx, NOx, Fine PM }\end{array}$ \\
\hline $\begin{array}{l}\text { Solar- } \\
\text { Photovoltaic } \\
\text { and } \\
\text { concentrating } \\
\text { (renewable) }\end{array}$ & $\begin{array}{l}\text { First generation } \\
\text { commercial, but very } \\
\text { high costs }\end{array}$ & 0.5 & $\begin{array}{l}\text { Costs unacceptably high, } \\
\text { solar resource intermittent in } \\
\text { many locations }\end{array}$ & $\begin{array}{l}\text { High, breakthrough R,D\&D } \\
\text { needed to develop \& demo } \\
\text { cells with higher efficiency } \\
\text { and lower capital costs }\end{array}$ & $\begin{array}{l}\text { Reduction in emissions of } \\
\text { SOx, NOx, Fine PM; fewer } \\
\text { mining impacts and residues }\end{array}$ \\
\hline $\begin{array}{l}\text { Biomass as } \\
\text { fuel and co- } \\
\text { fired with coal } \\
\text { (renewable) }\end{array}$ & $\begin{array}{l}\text { Commercial, steam } \\
\text { cycles }\end{array}$ & 0.5 & $\begin{array}{l}\text { Biomass dispersed source, } \\
\text { limited to } 20 \% \text { when co-fired } \\
\text { with coal }\end{array}$ & $\begin{array}{l}\text { Medium, biomass/IGCC } \\
\text { would enhance efficiency } \\
\text { and } \mathrm{CO}_{2} \text { benefit; also genetic } \\
\text { engineering to enhance } \\
\text { biomass plantations }\end{array}$ & $\begin{array}{l}\text { Reduction in emissions of } \\
\text { SOx, NOx, Fine PM; fewer } \\
\text { mining impacts and } \\
\text { Residues for disposal or use; } \\
\text { however potential eco } \\
\text { impacts from biomass } \\
\text { plantations }\end{array}$ \\
\hline $\begin{array}{l}\text { Hydroelectric } \\
\text { (renewable) }\end{array}$ & Commercial & 0.5 & $\begin{array}{l}\text { Capital costs high, potential } \\
\text { ecological disruption, siting } \\
\text { challenges }\end{array}$ & $\begin{array}{l}\text { Medium, minimize } \\
\text { environmental footprint }\end{array}$ & Ecosystem Impacts \\
\hline $\begin{array}{l}\text { More Efficient } \\
\text { Coal Fired } \\
\text { Power Plants }\end{array}$ & $\begin{array}{l}\text { Early } \\
\text { commercialization of } \\
\text { supercritical and ultra } \\
\text { supercritical }\end{array}$ & 0.2 & $\begin{array}{l}\text { Currently maximum efficiency } \\
\text { of } 45 \% \text {, yielding } 36 \% \text { less } \\
\mathrm{CO}_{2} \text { than current fleet }\end{array}$ & $\begin{array}{l}\text { High, new affordable } \\
\text { materials needed to enhance } \\
\text { efficiency to } 50 \text { to } 55 \%\end{array}$ & $\begin{array}{l}\text { Small reduction in emissions } \\
\text { of SOx, NOx, Fine PM; fewer } \\
\text { mining impacts and residues }\end{array}$ \\
\hline $\begin{array}{l}\text { Coal IGCC with } \\
\text { no CO2 } \\
\text { Capture and } \\
\text { Storage }\end{array}$ & $\begin{array}{l}\text { IGCC: early } \\
\text { commercialization }\end{array}$ & 0.2 & $\begin{array}{l}\text { IGCC: High capital costs, } \\
\text { complexity and reliability } \\
\text { concerns, only modest } \mathrm{CO} 2 \\
\text { savings without CCS }\end{array}$ & $\begin{array}{l}\text { High, Demos on a variety of } \\
\text { coals, hot gas cleanup } \\
\text { research }\end{array}$ & $\begin{array}{l}\text { Small reduction in emissions } \\
\text { of SOx, NOx, Fine PM; fewer } \\
\text { mining impacts and residues }\end{array}$ \\
\hline
\end{tabular}




\section{Building sector}

The building sector utilizes large quantities of electricity and fossil fuels and is expected to increase $\mathrm{CO}_{2}$ emissions for the next several decades at about $1.1 \%$ per year. Figure 4 illustrates the importance of this sector in the US, with commercial and residential buildings contributing $27.3 \%$ to national greenhouse gas emissions via use of electricity and direct use of fossil fuels, mostly natural gas and oil. Table 2 summarizes major technologies capable of achieving significant reductions in $\mathrm{CO}_{2}$ generation in the 2050 time frame. The technologies are divided into two categories: (1) heating and cooling and (2) appliances, which include lighting.

Table 2: Key technologies for $\mathrm{CO}_{2}$ avoidance from buildings (projected impact in $\mathrm{Gt} /$ year of $\mathrm{CO}_{2}$ ).

\begin{tabular}{|c|c|c|c|c|c|c|}
\hline & Technology & \begin{tabular}{|l} 
Current \\
State of the \\
Art
\end{tabular} & $\frac{2050}{\text { Impact }}$ & Issues & R,D\&D priority and Needs & $\begin{array}{l}\text { Other Potential } \\
\text { Environmental } \\
\text { Impacts }\end{array}$ \\
\hline \multirow{5}{*}{$\begin{array}{l}\text { H } \\
\mathrm{H} \\
\mathrm{a} \\
\mathrm{t} \\
\mathrm{i} \\
\mathrm{n} \\
\mathrm{g}\end{array}$} & \begin{tabular}{|l|} 
High efficiency \\
building envelope: \\
insulation, sealants, \\
windows
\end{tabular} & Commercial & 1.6 & \begin{tabular}{|l} 
Lack of incentive, \\
high initial costs, \\
long building \\
lifetime
\end{tabular} & $\begin{array}{l}\text { Low/medium priority, } \\
\text { incremental improvements to } \\
\text { lower cost and enhance } \\
\text { performance }\end{array}$ & $\begin{array}{l}\text { Reduction in coal } \\
\& \text { natural gas } \\
\text { emissions }\end{array}$ \\
\hline & $\begin{array}{l}\text { High efficiency } \\
\text { building heating and } \\
\text { cooling }\end{array}$ & Commercial & 1.1 & $\begin{array}{l}\text { Lack of incentive, } \\
\text { high initial costs }\end{array}$ & $\begin{array}{l}\text { Low/medium priority, } \\
\text { incremental improvements to } \\
\text { lower cost and enhance } \\
\text { performance }\end{array}$ & $\begin{array}{l}\text { Reduction in coal } \\
\& \text { natural gas } \\
\text { emissions }\end{array}$ \\
\hline & $\begin{array}{l}\text { Solar heating and } \\
\text { cooling }\end{array}$ & \begin{tabular}{|l} 
First \\
generation \\
commercial
\end{tabular} & 0.6 & $\begin{array}{l}\text { High initial costs, } \\
\text { availability of low } \\
\text { cost efficient } \\
\text { biomass heating } \\
\text { systems }\end{array}$ & $\begin{array}{l}\text { Medium, focus on } \\
\text { development of advanced } \\
\text { biomass stoves and solar } \\
\text { heating technology in } \\
\text { developing countries }\end{array}$ & $\begin{array}{l}\text { Reduction in coal } \\
\& \text { natural gas } \\
\text { emissions }\end{array}$ \\
\hline & $\begin{array}{l}\text { District Heating and } \\
\text { cooling }\end{array}$ & Commercial & 0.5 & \begin{tabular}{|l} 
Intial capital costs \\
high, CO2 benefit \\
variable; limited \\
applicability
\end{tabular} & $\begin{array}{l}\text { Low/medium, improve } \\
\text { economics for lower } \\
\text { population densities and } \\
\text { optimize system to include } \\
\text { cooling option }\end{array}$ & $\begin{array}{l}\text { Reduction in coal } \\
\& \text { natural gas } \\
\text { emissions }\end{array}$ \\
\hline & $\begin{array}{l}\text { Building energy } \\
\text { management }\end{array}$ & $\begin{array}{l}\text { First } \\
\text { generation } \\
\text { commercial }\end{array}$ & 0.2 & \begin{tabular}{|l|} 
Computer \\
technology not \\
being adequately \\
applied; lack of \\
incentive \& \\
knowledge
\end{tabular} & $\begin{array}{l}\text { Medium, integration and } \\
\text { operation research and tie in } \\
\text { with emergency demand } \\
\text { response measures }\end{array}$ & $\begin{array}{l}\text { Reduction in coal } \\
\& \text { natural gas } \\
\text { emissions }\end{array}$ \\
\hline $\begin{array}{l}A \\
p\end{array}$ & $\begin{array}{l}\text { More efficient } \\
\text { Electric appliances }\end{array}$ & Commercial & 2.1 & $\begin{array}{l}\text { Higher initial costs } \\
\text { and lack of } \\
\text { information to the } \\
\text { consumer }\end{array}$ & $\begin{array}{l}\text { Low/medium priority, } \\
\text { incremental improvements to } \\
\text { lower cost and enhance } \\
\text { performance }\end{array}$ & $\begin{array}{l}\text { Reduction in coal } \\
\text { \& gas emissions: } \\
\text { SOx, NOx and PM } \\
\text { and residues }\end{array}$ \\
\hline $\begin{array}{l}p \\
i \\
i \\
a\end{array}$ & $\begin{array}{l}\text { More efficient } \\
\text { lighting systems }\end{array}$ & $\begin{array}{l}\text { Commercial- } \\
\text { fluorescent }\end{array}$ & 1.0 & $\begin{array}{l}\text { Lack of incentive } \\
\text { given higher initial } \\
\text { costs }\end{array}$ & $\begin{array}{l}\text { Medium, LED and OLED } \\
\text { technology need further } \\
\text { development with aim of } \\
\text { lowering initial cost }\end{array}$ & $\begin{array}{l}\text { Reduction in coal } \\
\text { \& gas emissions: } \\
\text { SOx, NOx, PM } \\
\text { and residues }\end{array}$ \\
\hline $\begin{array}{l}\mathrm{n} \\
\mathrm{c} \\
\mathrm{e} \\
\mathrm{s}\end{array}$ & $\begin{array}{l}\text { Reduce stand-by } \\
\text { losses from } \\
\text { appliances, } \\
\text { computer } \\
\text { peripherals, etc. }\end{array}$ & Commercial & 0.3 & $\begin{array}{l}\text { Lack of incentive } \\
\text { from vendors and } \\
\text { lack of knowledge } \\
\text { from end-users }\end{array}$ & Low & $\begin{array}{l}\text { Reduction in coal } \\
\text { emissions: SOx, } \\
\text { NOx and PM and } \\
\text { residues }\end{array}$ \\
\hline
\end{tabular}


For each of the two categories, the technologies are listed in order of their potential impact in 2050 according to IEA. The technologies summarized in blue font are aimed at enhancing end use efficiency, whereas the rest deal with new alternative building heating/cooling technologies. It is important to note, that high-efficiency appliances and heating and cooling technologies are currently commercial. Lack of incentive and higher initial costs are the primary reasons for the slow rate of utilization. This is in contrast to the power generation sector, which is constrained by unavailable or undemonstrated technology.

\section{Transportation sector}

The transportation sector is growing at a fast rate, estimated at $2 \%$ per year between 2003 and 2050, driven by developing countries such as China and India, with a combined population of 2.3 billion or $37 \%$ of the world's population. It is second only to the power generation sector in importance for the foreseeable future. There are two major technology categories: vehicles and fuels. Technology is currently commercially available for major reductions in $\mathrm{CO}_{2}$ emissions per mile traveled, especially for light-duty vehicles. Table 3 summarizes the status of major technologies. The first two rows illustrate that major $\mathrm{CO}_{2}$ reductions could be achieved by incorporating the most efficient internal combustion, chassis, A/C and tire components. Also, hybrid technology, if optimized for efficiency and utilized with high-efficiency chassis components, can have a substantial positive impact. The main impediment to more robust utilization of these commercially available technologies appears to be higher initial costs for hybrids and buyer preferences that, in North America and more recently in Europe, are for larger, heavier, less-efficient vehicles.

IEA [4] projected that increasing and substantial quantities of $\mathrm{CO}_{2}$ will be emitted by gas and coal to liquid processes, in the energy transformation sector.

The author believes that processes generating liquid fuels from tar sands and oil shale could be major emitters as well. To the extent vehicle efficiency can be improved and renewable fuel options developed, major savings can be realized in the transformation sector.

Of all the biomass processes, thermo-chemical processes that can convert biomass to bio-diesel or other transportation fuels using gasification, pyrolysis, or Fischer-Tropsch technology, appear to have the most potential for $\mathrm{CO}_{2}$ mitigation and should be considered for an aggressive R, D \& D program.

Also, ethanol production by biochemical processing of biomass offers the potential for large-scale displacement of gasoline. However, breakthroughs will be necessary in the ability to chemically break down major biomass components to sugar for fermentation to produce ethanol.

Hydrogen/fuel cell vehicle technology is still in the early development stage, since the fuel cell stack still has limitations in terms of cost and longevity, and hydrogen storage in vehicles remains problematical. Also, EPA [10] and IEA [4] assessments suggest that $\mathrm{CO}_{2}$ savings would not be substantial unless or until the hydrogen could be generated from low-emission, renewable sources. 
Table 3: Candidate technologies for $\mathrm{CO}_{2}$ avoidance from mobile sources (projected impact in $\mathrm{Gt} /$ year of $\mathrm{CO}_{2}$ ).

\begin{tabular}{|c|c|c|c|c|c|c|}
\hline & Technology & \begin{tabular}{|l|} 
Current State \\
of the Art
\end{tabular} & $\frac{2050}{\text { Impact }}$ & Issues & R,D\&D Needs & $\frac{\text { Other Potential }}{\text { Environmental Impacts }}$ \\
\hline \multirow{4}{*}{$\begin{array}{l}\text { V } \\
\text { e } \\
\text { h } \\
\text { i } \\
\text { c } \\
\text { I } \\
\text { e } \\
\text { s }\end{array}$} & \begin{tabular}{|l} 
Improvements: \\
Current Internal \\
combustion engine \\
components
\end{tabular} & \begin{tabular}{l|} 
First \\
generation: \\
commercial
\end{tabular} & 2.2 & $\begin{array}{l}\text { Lack of customer incentive } \\
\text { major problem; trend to larger } \\
\text { vehicles in US and recently } \\
\text { Europe counter-productive }\end{array}$ & $\begin{array}{l}\text { Medium; Transmission } \\
\text { and drive train } \\
\text { improvements }\end{array}$ & $\begin{array}{l}\text { Lower emissions of } \\
\text { VOCs and Nox }\end{array}$ \\
\hline & $\begin{array}{l}\text { Non-engine } \\
\text { Improvements:tires } \\
\text {, A/C, light } \\
\text { materials }\end{array}$ & $\begin{array}{l}\text { First } \\
\text { generation: } \\
\text { commercial }\end{array}$ & 1.8 & $\begin{array}{l}\text { Lack of customer incentive } \\
\text { major problem; trend to larger } \\
\text { vehicles in US and Recently } \\
\text { Europe counter-productive }\end{array}$ & $\begin{array}{l}\text { Medium, Lower weight } \\
\text { construction, improved } \\
\text { tires and more efficient } \\
\text { A/Cs }\end{array}$ & $\begin{array}{l}\text { Lower emissions of } \\
\text { VOCs and Nox }\end{array}$ \\
\hline & Hybrid vehicles & $\begin{array}{l}\text { First } \\
\text { generation: } \\
\text { commercial }\end{array}$ & 1.4 & $\begin{array}{l}\text { Higher costs (about } \\
\$ 3000 \text { ),"light" hybrids not as } \\
\text { efficient as full hybrids, some } \\
\text { newer models yield power } \\
\text { over mileage benefits }\end{array}$ & $\begin{array}{l}\text { Medium/High,Minimize } \\
\text { incremental cost and } \\
\text { enhance efficiency }\end{array}$ & $\begin{array}{l}\text { Lower emissions of } \\
\text { VOCs and NOx }\end{array}$ \\
\hline & $\begin{array}{l}\text { Hydrogen fuel cell } \\
\text { vehicles }\end{array}$ & Developmental & 0 & $\begin{array}{l}\text { Fuel cell costs and fuel cell } \\
\text { stack life; also hydrogen } \\
\text { storage, safety and lack of } \\
\text { infrastructure }\end{array}$ & $\begin{array}{l}\text { High, Breakthrough } \\
\text { R,D\&D needed to develop } \\
\text { cost competitive, long lived } \\
\text { fuel cells. Vehicle storage } \\
\text { R,D\&D also needed }\end{array}$ & $\begin{array}{l}\text { On road emissions close } \\
\text { to zero, } \mathrm{H} 2 \text { production } \\
\text { emissions depends on } \\
\text { feedstock \& process }\end{array}$ \\
\hline \multirow{6}{*}{$\begin{array}{l}\mathrm{F} \\
\mathrm{u} \\
\mathrm{e} \\
\mathrm{I} \\
\mathrm{s}\end{array}$} & Ehanol from sugar & Commercial & 0.7 & $\begin{array}{l}\text { Limited by land capable of } \\
\text { high sugar yields,e.g., sugar } \\
\text { cane }\end{array}$ & $\begin{array}{l}\text { Medium, develop sugar } \\
\text { cane cultivars with higher } \\
\text { yield and more frost } \\
\text { tolerant }\end{array}$ & $\begin{array}{l}\text { Potential eco impacts } \\
\text { from biomass } \\
\text { plantations, other } \\
\text { impacts unclear, } \\
\text { environmental studies } \\
\text { would be useful }\end{array}$ \\
\hline & $\begin{array}{l}\text { Biodiesel \& other } \\
\text { fuels from } \\
\text { biomass; } \\
\text { thermochemical } \\
\text { processes }\end{array}$ & Developmental & 0.6 & $\begin{array}{l}\text { Developmental,yet potentially } \\
\text { high production and lower } \\
\text { cost via gasification/Fischer- } \\
\text { Tropsch synthesis }\end{array}$ & $\begin{array}{l}\text { High, Breakthrough } \\
\text { R,D\&D needed to develop } \\
\text { and demonstrate viable } \\
\text { technology for biomass } \\
\text { feedstock }\end{array}$ & $\begin{array}{l}\text { Potential eco impacts } \\
\text { from biomass } \\
\text { plantations, other } \\
\text { impacts unclear, } \\
\text { environmental studies } \\
\text { would be useful }\end{array}$ \\
\hline & $\begin{array}{l}\text { Biodiesel from } \\
\text { vegetable oil }\end{array}$ & $\begin{array}{l}\text { First } \\
\text { generation: } \\
\text { commercial }\end{array}$ & 0.2 & $\begin{array}{l}\text { High costs, low yield from oil } \\
\text { crops, limited waste cooking } \\
\text { oils, low S a plus }\end{array}$ & Low & $\begin{array}{l}\text { Not clear, environmental } \\
\text { characterization would } \\
\text { be useful }\end{array}$ \\
\hline & $\begin{array}{l}\text { Ethanol from } \\
\text { grain/starch,e.g., } \\
\text { corn }\end{array}$ & Commercial & 0.2 & $\begin{array}{l}\text { Limited by grain supply; high } \\
\text { costs, energy intensive } \\
\text { production }\end{array}$ & Low & $\begin{array}{l}\text { Modest delta impacts } \\
\text { compared to base case }\end{array}$ \\
\hline & $\begin{array}{l}\text { Ethanol from } \\
\text { biomass; } \\
\text { biochemical } \\
\text { process }\end{array}$ & \begin{tabular}{|l|} 
Early \\
Developmental
\end{tabular} & 0 & $\begin{array}{l}\text { Inability to convert all } \\
\text { biomass components, high } \\
\text { production costs, dispersed } \\
\text { biomass source }\end{array}$ & $\begin{array}{l}\text { High, Breakthrough } \\
\text { R,D\&D needed to develop } \\
\text { lower cost generally } \\
\text { applicable process(es) }\end{array}$ & $\begin{array}{l}\text { Not clear, environmental } \\
\text { characterization would } \\
\text { be useful }\end{array}$ \\
\hline & Hydrogen & $\begin{array}{l}\text { Commercial } \\
\text { from natural } \\
\text { gas and } \\
\text { electricity }\end{array}$ & 0 & $\begin{array}{l}\text { Cost via electrolysis high, } \\
\mathrm{CO} 2 \text { benefits if produced via } \\
\text { natural gas low }\end{array}$ & $\begin{array}{l}\text { High; breakthrough } \\
\text { research to generate } \mathrm{H} 2 \text { at } \\
\text { low cost from renewable or } \\
\text { nuclear sources }\end{array}$ & $\begin{array}{l}\text { Depends upon feedstock } \\
\text { source and production } \\
\text { process }\end{array}$ \\
\hline
\end{tabular}

Despite the serious technical issues, in light of the ultimate potential of fuel cell /hydrogen and biochemical ethanol, the author believes both are also strong candidates for an aggressive R, D, \& D focus with the aim of breakthrough technology.

\section{Industrial sector}

$\mathrm{CO}_{2}$ emissions from the industrial sector are projected to grow at an annual rate of $0.7 \%$ per year over the next several decades. Table 4 summarizes major technologies applicable to this sector. Although $\mathrm{CO}_{2}$ emission control can be specific to a particular industry, there are a number of technologies that can be 
Table 4: Candidate technologies for $\mathrm{CO}_{2}$ avoidance from industrial sources (impact in $\mathrm{Gt} /$ year of $\mathrm{CO}_{2}$ ).

\begin{tabular}{|c|c|c|c|c|c|}
\hline Technology & \begin{tabular}{|l|} 
Current State \\
of the Art \\
\end{tabular} & \begin{tabular}{|l|}
2050 \\
Impact
\end{tabular} & Issues & R,D\&D Needs & $\begin{array}{l}\text { Other Potential } \\
\text { Environmental } \\
\text { Impacts }\end{array}$ \\
\hline Motor Systems & Commercial & 1.5 & $\begin{array}{l}\text { For most industries not } \\
\text { a major cost; lack of } \\
\text { expertise for some } \\
\text { industries }\end{array}$ & $\begin{array}{l}\text { Medium; lower costs } \\
\text { and higher } \\
\text { efficiencies desirable }\end{array}$ & $\begin{array}{l}\text { Reduction in coal } \\
\text { emissions: SOx, NOx; } \\
\text { and PM and residues }\end{array}$ \\
\hline $\begin{array}{l}\text { CO2 Capture and } \\
\text { Storage }\end{array}$ & \begin{tabular}{|l} 
Early \\
development
\end{tabular} & 1.5 & $\begin{array}{l}\text { Applicability limited to } \\
\text { large energy-intensive } \\
\text { industries; key } \\
\text { questions:cost, safety, } \\
\text { efficacy }\end{array}$ & $\begin{array}{l}\text { High, major program } \\
\text { with long term demos } \\
\text { evaluating large } \\
\text { number of geological } \\
\text { formations to } \\
\text { evaluate efficacy, } \\
\text { cost and safety }\end{array}$ & $\begin{array}{l}\text { Lower power plant } \\
\text { efficieny yields greater } \\
\text { emissions of SOx, } \\
\text { NOx, Fine PM }\end{array}$ \\
\hline \begin{tabular}{|l|} 
Fuel Substitution \\
in Basic Materials \\
Production
\end{tabular} & Commercial & 0.5 & $\begin{array}{l}\text { Natural gas substiution } \\
\text { for oil and coal can be } \\
\text { expensive }\end{array}$ & Low & $\begin{array}{l}\text { Unclear, } \\
\text { environmental studies } \\
\text { useful }\end{array}$ \\
\hline $\begin{array}{l}\text { Enhanced energy } \\
\text { efficiency: } \\
\text { existing basic } \\
\text { material } \\
\text { processes }\end{array}$ & Commercial & 0.4 & $\begin{array}{l}\text { Developing countries } \\
\text { can have low energy } \\
\text { efficiency due to lack } \\
\text { of incentive and/or } \\
\text { expertise }\end{array}$ & Low & $\begin{array}{l}\text { Unclear, } \\
\text { environmental studies } \\
\text { useful }\end{array}$ \\
\hline $\begin{array}{l}\text { Feedstock } \\
\text { Substitution in } \\
\text { key industries }\end{array}$ & Commercial & 0.4 & $\begin{array}{l}\text { Biomass and } \\
\text { biopastics can } \\
\text { substitute for } \\
\text { petroleum feedstocks } \\
\text { and products; however } \\
\text { cost high \& availability } \\
\text { low }\end{array}$ & $\begin{array}{l}\text { Medium, develop } \\
\text { affordable substitute } \\
\text { feedstocks and } \\
\text { products based on } \\
\text { biomass }\end{array}$ & $\begin{array}{l}\text { Unclear, } \\
\text { environmental studies } \\
\text { useful, depends on } \\
\text { feedstock \& process }\end{array}$ \\
\hline $\begin{array}{l}\text { Steam systems } \\
\text { (required for } \\
\text { many industries) }\end{array}$ & Commercial & 0.3 & $\begin{array}{l}\text { For most industries not } \\
\text { a major cost; lack of } \\
\text { expertise for some } \\
\text { industries }\end{array}$ & Low & $\begin{array}{l}\text { Reduction in coal } \\
\text { emissions: SOx, NOx } \\
\text { and PM and residues }\end{array}$ \\
\hline $\begin{array}{l}\text { Materials/Product } \\
\text { Efficiency }\end{array}$ & \begin{tabular}{|l|} 
First \\
generation: \\
commercial
\end{tabular} & 0.3 & \begin{tabular}{|l|} 
Little incentive to \\
minimize the $\mathrm{CO} 2$ \\
"content" of materials \\
and products; life cycle \\
analyses required
\end{tabular} & \begin{tabular}{|l|} 
Medium, conduct life \\
cycle analyses of key \\
materials and \\
products with the aim \\
of minimizing $\mathrm{CO} 2$ \\
"content"
\end{tabular} & $\begin{array}{l}\text { Potential reduction in } \\
\text { air emissions, water } \\
\text { effluents and wastes, } \\
\text { depenging on } \\
\text { substitute material }\end{array}$ \\
\hline $\begin{array}{l}\text { Cogeneration } \\
\text { (combined heat } \\
\text { and power) }\end{array}$ & Commercial & 0.3 & $\begin{array}{l}\text { Limited by electric grid } \\
\text { access that would } \\
\text { allow the ability to feed } \\
\text { electricity back to grid, } \\
\text { also high capital costs }\end{array}$ & Low & $\begin{array}{l}\text { Reduction in coal } \\
\text { emissions: SOx, NOx } \\
\text { and PM and residues }\end{array}$ \\
\hline $\begin{array}{l}\text { Enhanced energy } \\
\text { efficiency: new } \\
\text { basic material } \\
\text { processes }\end{array}$ & \begin{tabular}{|l|} 
Development \\
al to Near- \\
commercial \\
depending on \\
industry
\end{tabular} & 0.2 & $\begin{array}{l}\text { New, innovative } \\
\text { production processes } \\
\text { require major R,D\&D } \\
\text { and would need } \\
\text { reasonble payback to } \\
\text { replace more C } \\
\text { intensive processes }\end{array}$ & \begin{tabular}{|l|} 
Medium/High, \\
Develop and \\
demonstrate less \\
carbon intensive \\
production processes \\
for key industries
\end{tabular} & $\begin{array}{l}\text { Potential reduction in } \\
\text { air emissions, water } \\
\text { effluents and wastes, } \\
\text { depending on new } \\
\text { process }\end{array}$ \\
\hline
\end{tabular}


applied to a large fraction of the industrial sector (blue font in Table 4). Generally applicable technologies include: more efficient motors and steam generators and enhanced use of cogeneration technology; all are commercially available and offer the potential for major reductions. For the larger, more energy intensive industries such as cement kilns, ammonia production, and blast furnaces, $\mathrm{CO}_{2}$ capture and storage also offers potential for mitigating large quantities of $\mathrm{CO}_{2}$. However, as mentioned earlier, $\mathrm{CCS}$ is in the early developmental stage with a host of questions that can only be resolved through a major program with a particular focus on demonstrations for key geological formations.

Developing and deploying new or modified industrial production processes can also yield important $\mathrm{CO}_{2}$ emission mitigation potential. Processes can be modified to utilize more environmentally-friendly feedstocks, or fundamentally new basic material processes can be introduced with inherently less energy

Another approach that has potential is to encourage utilization of products which have lower $\mathrm{CO}_{2}$ "content," i.e., require less carbon intensive energy during the their production, use, and disposal. These could be considered "climate-friendly" products. There is currently no incentive to use such products. Also, comprehensive life cycle analyses would be necessary to quantify product $\mathrm{CO}_{2}$ "content".

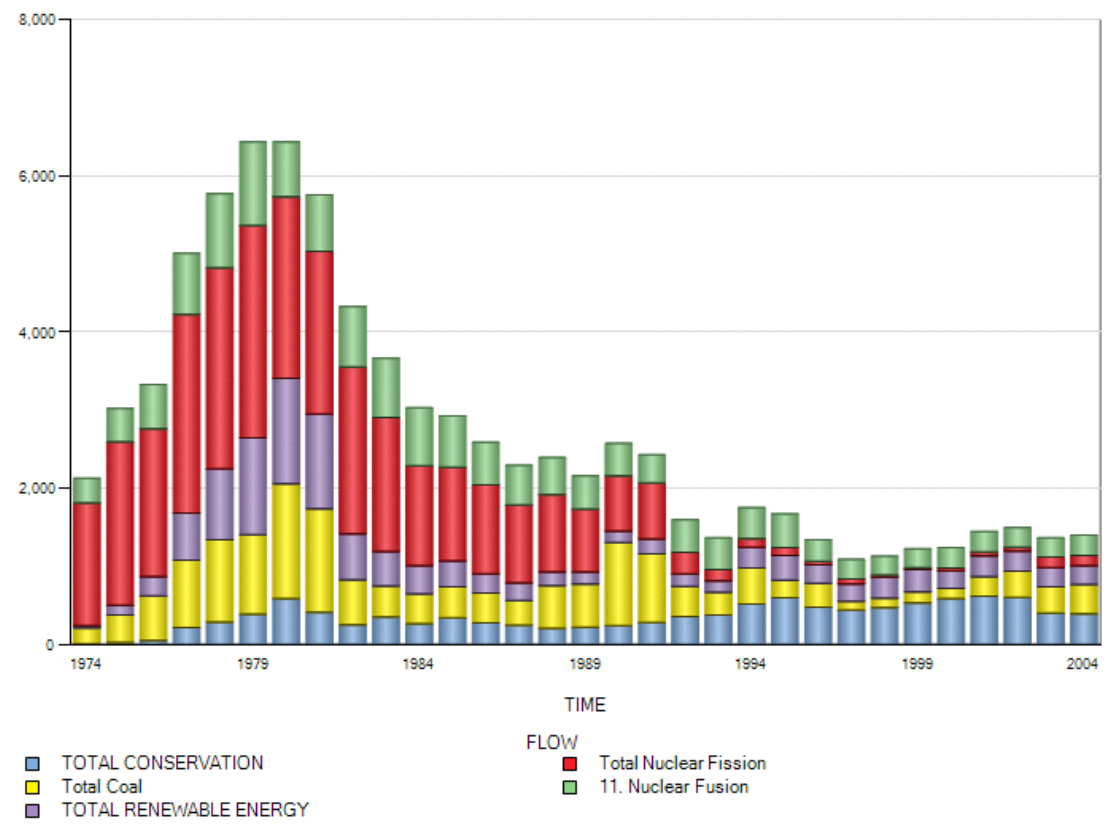

Figure 8: U.S. Federal R, D, \&D expenditures for key energy sectors, 2004 \$. 


\section{Adequacy of R, D, \&D}

IEA [4], Hawksworth [8], Morgan et al. [10], and the author nine years ago (Princiotta [13]) have observed that R, D, \& D funding in the energy area will need to be substantially increased in order for key technologies to be ready to reduce carbon dioxide emissions in a time frame consistent with an aggressive mitigation program. Most recently, The Stern Report [14] concluded: “....support for energy R\&D should at least double, and support for the deployment of new low-carbon technologies should increase up to five-fold."

Figures 8 and 9, generated from IEA [15], depict U.S. and world research expenditures in critical areas: nuclear power, coal, conservation, and renewables. (Note that world expenditures have only been compiled since 1992.) As can be seen, in the U.S., there has been a major decrease in funding since the $1980 \mathrm{~s}$, with no major increases in recent years. It is also noteworthy that Europe and Japan have been much more active in the nuclear research area, whereas the U.S. is the key player in coal-related research.

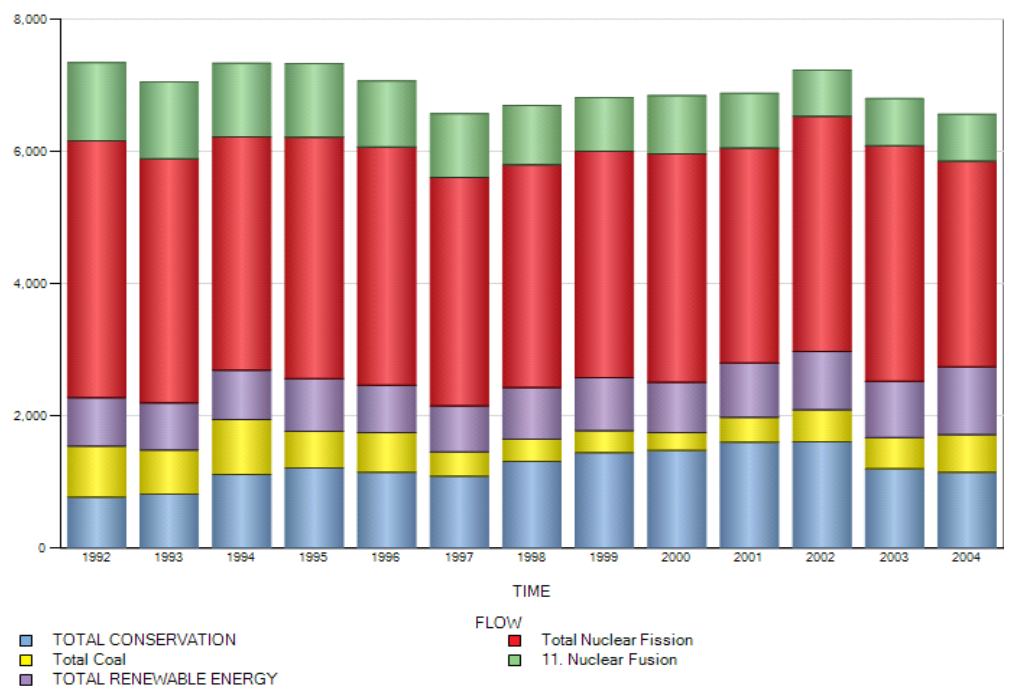

Figure 9: World R, D, \& D expenditures for key energy sectors, 2004 \$.

It should be recognized that in the last few years, the U.S. has redirected some of its research resources to some key technologies, especially: hydrogen/fuel cells, IGCC, carbon capture and storage, and most recently biomass to ethanol technologies. The U.S. has coordinated its efforts in this area through the Climate Change Technology Program, CCTP [16]. Within the constraint of current budget priorities, the CCTP has coordinated a diversified portfolio of advanced technology R \& D, focusing on: energy-efficiency enhancements; lowGHG-emission energy supply technologies; carbon capture, storage, and sequestration methods; and technologies to reduce emissions of non- $\mathrm{CO}_{2}$ gases. 
This could provide a foundation for an expanded program, with funding and schedules consistent with an aggressive mitigation program. Also, the USEPA [17] is implementing a series of voluntary programs which encourage greenhouse gas reduction. They include: Energy Star for the building sector, transportation programs and non- $\mathrm{CO}_{2}$ emission reduction programs in collaboration with industry.

It is important to note, that IGCC and most of the other non-coal technologies offer the potential for lower air emissions, water effluents and waste generation residues. Also, note that the transportation technologies all offer the potential for reducing our dependency on foreign oil. Further, the country or countries that can bring these technologies to market first, has/have the potential for major revenue streams from what could be a huge international market.

\section{Summary and conclusions}

The key energy sectors are power generation, transportation, industrial production, and buildings. The power sector and transportation sectors are particularly important, since they are projected to grow at relatively high rates, with China and India being key drivers.

The power generation sector, projected to grow from a large base at $2 \%$ annually, offers the greatest opportunity for $\mathrm{CO}_{2}$ reductions. However, since the key source of emissions is coal combustion, it is critically important to develop affordable $\mathrm{CO}_{2}$ mitigation technologies for such sources. $\mathrm{CCS}$ offer the potential to allow coal use while at the same time mitigating $\mathrm{CO}_{2}$ emissions. These technologies could be applied to current pulverized coal (PC) boilers, but current $\mathrm{CO}_{2}$ scrubbing technology is too energy intensive and expensive for PC conditions. Therefore, alternatives to PC boilers are important. The two major candidates are IGCC and oxygen-fed combustors, both of which can remove $\mathrm{CO}_{2}$ more affordably for ultimate sequestration. However, CCS is an unproven technology with many serious cost, efficacy, and safety issues. Nuclear power plants, natural gas/combined cycle plants, and wind turbines all have the potential to make significant contributions.

The building sector is where much of the electricity generated is utilized and where there are many currently available technologies that can significantly reduce the use of electricity and other energy sources, with a corresponding decrease in $\mathrm{CO}_{2}$ emissions. The constraints here are less technological and more socioeconomic. However, to the extent R \& D can lower cost and raise efficiency of building components, it can help provide extra incentive for building owners to invest in the most efficient heating and cooling systems, lighting, and appliances.

The transportation sector is growing at a rate of $2 \%$ per year. The challenge in this sector is two-fold. The first challenge is that current propulsion systems all depend on fossil fuels with their associated $\mathrm{CO}_{2}$ emissions, suggesting that technologies based on renewable sources such as biomass would be important. The second challenge is that the automobile industry, driven by consumer preferences (especially in North America), have offered heavy, inefficient 
vehicles such as SUVs. A review of developing technologies suggests that hybrid vehicles and biomass-to-diesel fuel via thermochemical processing are the most promising. However, cellulosic biomass-to-ethanol and hydrogen/fuel cell vehicles offer longer term potential if key technical issues are resolved and, in the case of hydrogen, renewable sources are developed.

Industrial sector emissions are projected to grow at an annual rate of $0.7 \%$. Although $\mathrm{CO}_{2}$ emission controls can be specific to a particular industry, the following key commercial technologies can be applied to a large fraction of the industrial sector: efficient motors, steam generators, and enhanced use of cogeneration technology. For the larger, more energy-intensive industries, such as blast furnaces, $\mathrm{CO}_{2}$ capture and storage offer the potential for mitigating large quantities of $\mathrm{CO}_{2}$. Developing and deploying new or modified industrial production processes can also yield important $\mathrm{CO}_{2}$ emission mitigation potential. Another attractive approach is to encourage utilization of products that have a lower $\mathrm{CO}_{2}$ content," i.e., require less carbon intensive energy during product production, use, and disposal.

If mitigation consistent with the IEA scenario is to be accomplished, a major increase in R\&D resources will be needed. Technology research, development, and demonstration are of particular importance for coal generation technologies: IGCC, oxygen coal combustion, and $\mathrm{CO}_{2}$ capture technology for pulverized coal combustors. All of these technologies will have to be integrated with underground storage, a potentially breakthrough technology, but one which is an early stage of development. Also important are next generation nuclear power plants, biomass to diesel fuel processes, cellulosic biomass-to-ethanol production technology, and hydrogen production technology.

Availability of key technologies will be necessary but not sufficient to limit $\mathrm{CO}_{2}$ emissions. Since many of these technologies have higher costs and/or greater operational uncertainties than currently available carbon intensive technologies, robust policies will be necessary to encourage their utilization.

Finally, given the challenge and uncertainties associated with an aggressive mitigation program based in part on unproven, developmental technologies, it may be prudent to consider all available and emerging technologies. This suggests that fundamental research on energy technologies in addition to those in Tables 1 to 4 , be part of the global research portfolio, since breakthroughs on today's embryonic technologies could yield tomorrow's alternatives. Also, it may also be prudent to consider geoengineering options, which although radical in concept, could potentially buy the time needed to make the necessary adjustments in our energy and industrial infrastructure consistent with an aggressive mitigation program. For example, it is suggested that the simulated volcano option proposed by Wigley [7] be seriously evaluated.

\section{References}

[1] IPCC (2001), Mitigating Climate Change Summary for Policymakers, Third Assessment Report of the Intergovernmental Panel on Climate Change, Cambridge University Press 
[2] National Center for Atmospheric Research (NCAR), web page, http://www.ucar.edu/research/climate/warming.shtml

[3] World Resources Institute (2006): Climate Analysis Indicators Tool (CAIT) on-line database version 3.0., Washington, DC: World Resources Institute, available at: http://cait.wri.org

[4] International Energy Agency, Energy Technology Perspectives 2006, OECD-IEA, 2006

[5] World Resources Institute, U.S. GHG Emissions Flow Chart: http://cait.wri.org/figures.php?page $=$ US-FlowChart\&view=100, 2006

[6] Wigley, T.M.L. and Raper, S.C.B., Interpretation of high projections for global-mean warming. Science 293, 451-454.MAGICC (Model for the Assessment of Greenhouse gas Induced Climate Change) can be downloaded at http://www.cgd.ucar.edu/cas/wigley/magicc/index.htm, 2001

[7] Wigley, T. M. A Combined Mitigation/Geoengineering Approach to Climate Stabilization, Science 314 (5798), 452. [DOI: 10.1126/science.1131728] (20 October 2006)

[8] Hawksworth, J., The World in 2050; Implications of global growth for carbon emissions and climate change policy, PriceWaterhouseCoopers, September 2006

[9] Pacala, S. \& Socolow, R., Stabilization wedges: solving the climate problem for the next 50 years with current technologies. Science 305 , 968-972. 2004

[10] Morgan, G., Apt, J., Lave L., The U.S, Electric Power Sector and Climate Change Mitigation, Pew Center:2006

[11] USEPA:Yeh S, Loughlin D., Shay C., Gage C., An Integrated Assessment of the Impacts of Hydrogen Economy on Transportation, Energy Use and Air Emissions, Proceeding of the IEEE Special Issue: Hydrogen Economy, June 28, 2006

[12] USEPA: DeCarolis J., Shay C., Vijay S, The Potential Mid-Term Role of Nuclear Power in the United States: A Scenario Analysis Using MARKAL, Proposed Book Chapter, 2006

[13] Princiotta, F.T., Renewable technologies and their role in mitigating greenhouse gas warming, Elsevier Science Publishers, US-Dutch symposium: Facing the air pollution agenda for the $21^{\text {st }}$ century, vol. 72, 1998

[14] Stern, N., The Economics of Climate Change, The Stern Review, 2006 pre-publication version: website: http://www.hm-treasury.gov.uk /independent_reviews/stern_review_economics_climate_change/stern_rev iew_report.cfm

[15] InternationalEnergyAgency, RD\&DBudgets, website: http://www.iea.org /RDD/TableViewer/

[16] CCTP, Climate Change Technology Program, website: http://www.climatetechnology.gov/.

[17] USEPA, Current and Near Term Greenhouse gas Reduction Initiative, website: www.epa.gov/climatechange/policy/neartermghgreduction.html 